\title{
An American patient with polyposis carrying a Scandinavian AXIN2 pathogenic variant
}

\author{
Sarah K. Macklin-Mantia ${ }^{1}$ and Douglas L. Riegert-Johnson ${ }^{1,2^{*}}$
}

Keywords: AXIN2, Hereditary cancer syndrome, Hereditary polyposis, Cancer, Hypodontia

To the Editor,

We report the case of an AXIN2 pathogenic variant carrier. AXIN2 is a component of the beta catenin destruction complex of the canonical Wnt signaling pathway. AXIN2 pathogenic variants decrease beta catenin destruction and increase Wnt signaling. APC is one of the other components and germline pathogenic variants in $A P C$ are associated with familial adenomatous polyposis [1].

AXIN2 pathogenic variants are associated with the absence of permanent teeth (hypodontia), sparse hair and eye brows (ectodermal dysplasia), and gastrointestinal polyps and cancer. Inheritance is autosomal dominant with variable penetrance. About 30 other cases have been reported since the first cases 17 years ago [2-6]. Given the rarity of pathogenic variants in $A X I N 2$, each additional case report is helpful in clarifying the phenotype. This clinical report is noteworthy for being the first of a Scandinavian pathogenic variant carrier outside of Scandinavia and the first report of colonoscopy findings for the AXIN2 c.1994dupG pathogenic variant.

The patient was a 65 year-old white man referred by his local gastroenterologist in January of 2020. His past medical history included prostate adenocarcinoma (62 years of age, treated with radiation therapy), skin cancer (60 years of age, type unknown), rheumatoid arthritis, glaucoma, hypertension, and obstructive sleep apnea.

\footnotetext{
* Correspondence: riegertjohnson.douglas@mayo.edu

${ }^{1}$ Department of Clinical Genomics, Mayo Clinic, 4500 San Pablo Road South, Jacksonville, FL 32224, USA

${ }^{2}$ Department of Gastroenterology, Mayo Clinic, 4500 San Pablo Road South, Jacksonville, FL 32224, USA
}

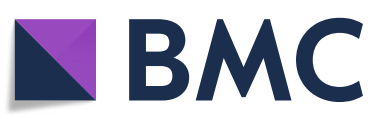

(c) The Author(s). 2020 Open Access This article is licensed under a Creative Commons Attribution 4.0 International License, which permits use, sharing, adaptation, distribution and reproduction in any medium or format, as long as you give appropriate credit to the original author(s) and the source, provide a link to the Creative Commons licence, and indicate if changes were made. The images or other third party material in this article are included in the article's Creative Commons licence, unless indicated otherwise in a credit line to the material. If material is not included in the article's Creative Commons licence and your intended use is not permitted by statutory regulation or exceeds the permitted use, you will need to obtain permission directly from the copyright holder. To view a copy of this licence, visit http://creativecommons.org/licenses/by/4.0/. The Creative Commons Public Domain Dedication waiver (http://creativecommons.org/publicdomain/zero/1.0/) applies to the data made available in this article, unless otherwise stated in a credit line to the data.
On physical examination, he had no features of ectodermal dysplasia and 25 teeth. (Normal adult number of teeth is 32). The patient had had several teeth removed due to decay, and he may have also had absence of permanent teeth. The ongoing COVID-19 pandemic has prevented the patient from attending an expert dental consultation for further evaluation.

The patient has had 57 adenomatous colon polyps removed during four colonoscopies (June 2019, August 2019, November 2019, and March 2020). An upper endoscopy in March of 2020 showed no polyps. Strategies for management of his colon polyps were presented to the patient. For surgery, we offered laparoscopic subtotal colectomy with follow up flexible sigmoidoscopy every six to twelve months. For colonoscopy, we recommended a procedure every six to twelve months based on the number of polyps found. For the present, the patient has chosen to continue with colonoscopy.

The patient had limited information on his ancestry and family history; what is known is written below or shown in Fig. 1. He knew of no connection to Scandinavia. He was born in a small town in southeast Georgia, USA with a current population under 15,000 individuals. His mother and father were born in separate, smaller, nearby towns in Georgia with populations less than 5, individuals. His mother died at 66 years of age from lung cancer, and his father died at 72 years of age from complications of hypertension. No other family members have had AXIN2 genetic testing, colonoscopy, or are known to have dental abnormalities. The patient's family was counseled on their risk and offered cascade testing. 


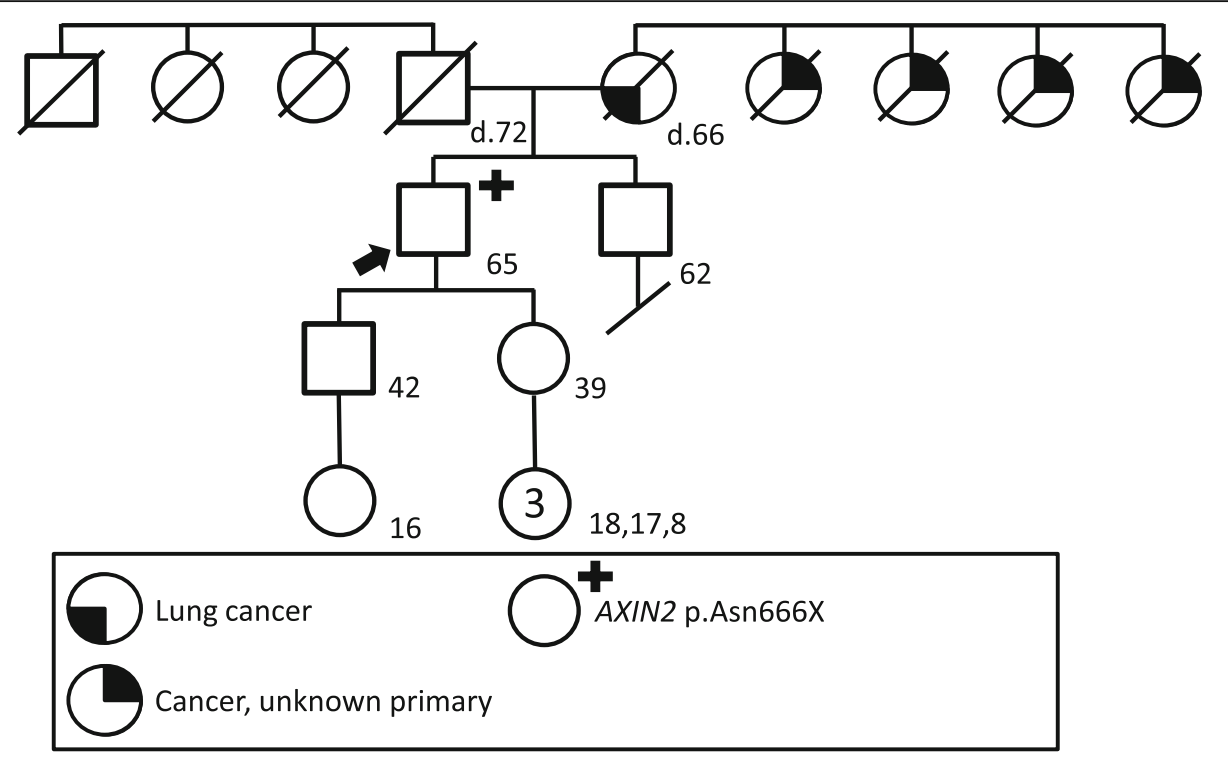

Fig. 1 Pedigree. The arrow points to the proband carrying the AXIN2 C.1994dupG pathogenic variant. Current ages or age at death are noted to the right of pedigree symbols.

With the ongoing COVID-19 pandemic, they do not feel it is safe to travel from their rural home to Mayo Clinic Florida for testing.

Germline genetic testing was ordered through a commercial genetic testing laboratory and included analysis of 70 genes (Ambry genetics - Aliso Viejo, California CancerNext Expanded with MSH3, NTHL1, and AXIN2 added). A pathogenic variant was detected in AXIN2, c.1994dupG, located in exon 7, which causes a translational frameshift with a predicted alternate stop codon (p.N666Qfs"41) (NM_004655.3) (ClinVar ID: 536512).

The c.1994dupG pathogenic variant found is the same identified in the initial 2004 Finnish AXIN2 publication as a de novo case by Lammi and others. The variant was also reported in 2011 by Bergendal and others from Sweden. All reported c.1994dupG cases had oligodontia, none had ectodermal dysplasia, and none had had a colonoscopy. The genome aggregation database (GnomAD) was accessed April 3, 2020 and searched for data on the c.1994dup G variant (17-63,532,584-G-GC (GRCh37). The allele frequency was 0.0006954 (17 heterozygotes). Interestingly, three heterozygotes were in the African population, the others were European (non-Finnish) (12), Finnish (1), and Ashkenazi Jewish (1).

The identification of an American carrier of this pathogenic AXIN2 variant previously found in Scandinavia raises the possibility of an unidentified, large, American AXIN2 pathogenic variant family. The same variant reported here has also been reported into ClinVar by another American laboratory. Single nucleotide insertions, such as 1994dupG, are relatively uncommon de novo events and unlikely to be recurrent. The AXIN2
1994dupG variant likely follows the common motif in hereditary cancer syndromes of the identification of seemingly unrelated families in the United States with the same pathogenic variant eventually shown to have common descent to a European ancestor (e.g. EPCAM pathogenic variants [7].

The small number of known cases with germline AXIN2 pathogenic variants makes it challenging to accurately assess risks for these individuals. We would ask that any clinicians treating patients with AXIN2 pathogenic variants contact us. Our group, working with genetic testing laboratories and clinicians, is building an AXIN2 patient registry.

\section{Acknowledgements}

None.

\section{Authors' contributions}

Ms. Mantia-Macklin and Dr. Riegert-Johnson each participated in the writing of the letter. The author(s) read and approved the final manuscript.

\section{Funding}

None.

Ethics approval and consent to participate

IRB policies of the Mayo Clinic have been followed.

Consent for publication

IRB policies of the Mayo Clinic have been followed.

Competing interests

None. 
Received: 2 June 2020 Accepted: 24 July 2020

Published online: 30 July 2020

\section{References}

1. Mazzoni SM, Fearon ER. AXIN1 and AXIN2 variants in gastrointestinal cancers. Cancer Lett. 2014;355(1):1-8. https://doi.org/10.1016/..canlet.2014.09.018.

2. Lammi L, Arte S, Somer M, Jarvinen H, Lahermo P, Thesleff I, et al. Mutations in AXIN2 cause familial tooth agenesis and predispose to colorectal cancer. Am J Hum Genet. 2004. https://doi.org/10.1086/386293.

3. Bergendal B, Klar J, Stecksen-Blicks C, Norderyd J, Dahl N. Isolated Oligodontia associated with mutations in EDARADD, AXIN2, MSX1, and PAX9 genes. Am J Med Genet Part A. 2011. https://doi.org/10.1002/ajmg.a.34045.

4. Marvin ML, Mazzoni SM, Herron CM, Edwards S, Gruber SB, Petty EM. AXIN2associated autosomal dominant ectodermal dysplasia and neoplastic syndrome. Am J Med Genet A. 2011. https://doi.org/10.1002/ajmg.a.33927.

5. Rivera B, Perea J, Sánchez E, Villapún M, Sánchez-Tomé E, Mercadillo F, et al. A novel AXIN2 germline variant associated with attenuated FAP without signs of oligondontia or ectodermal dysplasia. Eur J Hum Genet. 2014 https://doi.org/10.1038/ejhg.2013.146.

6. Beard C, Purvis R, Winship IM, Macrae FA, Buchanan DD. Phenotypic confirmation of oligodontia, colorectal polyposis and cancer in a family carrying an exon 7 nonsense variant in the AXIN2 gene. Familial Cancer. 2019. https://doi.org/10.1007/s10689-019-00120-0.

7. Lynch HT, Riegert-Johnson DL, Snyder C, Lynch JF, Hagenkord J, Boland CR, et al. Lynch syndrome-associated extracolonic tumors are rare in two extended families with the same EPCAM deletion. Am J Gastroenterol. 2011. https://doi.org/10.1038/ajg.2011.203.

\section{Publisher's Note}

Springer Nature remains neutral with regard to jurisdictional claims in published maps and institutional affiliations.

Ready to submit your research? Choose BMC and benefit from:

- fast, convenient online submission

- thorough peer review by experienced researchers in your field

- rapid publication on acceptance

- support for research data, including large and complex data types

- gold Open Access which fosters wider collaboration and increased citations

- maximum visibility for your research: over $100 \mathrm{M}$ website views per year

At BMC, research is always in progress.

Learn more biomedcentral.com/submissions 